\title{
Revitalisasi Filosofi Ornamen Bermotif Melayu pada Desain Corak Anyaman Gedebong Pisang: Kajian Kearifan Lokal Budaya Melayu
}

\author{
Juliana, Hetty Zaharani \\ Universitas Potensi Utama \\ juliana@potensi-utama.ac.id*,tyzaharani@gmail.com \\ DOI 10.20884/jli.v10i1.1541
}

\begin{abstract}
Article History:
First Received:

ABSTRACT

$2019 / 05 / 17$

Final Revision:

$2019 / 06 / 20$

Available online:

This article aims to revitalize the phylosophy of Malay motif ornament in the design of woven gedebong. This research uses a qualitative descriptive method with ethnographic approach. The data were collected through observation, interview and documentation. There were four motifs used to revitalize and develop philosophical of Malay culture in the design of woven gedebong, they were flora, fauna, natural and wajik motifs. Firstly, flora motifs ornaments are from lined up flower (bunga berjajar), reap flower (bunga tampuk manggis), single florets (kuntum bujang), gundur florets, cloudy florets (kuntum awan larat), eartquake motion flower (bunga gerak gempa) on the handicraft of pencil case, cake box, skewer, kleenex box. Secondly, fauna motifs ornaments are from dragon (naganagaan) ant (semut beriring), twinned pigeon (merpati sekawan), return home duckling (itik pulang petang) on the handicrafts of sandal, kleenex box, and hat. Thirdly, outer space buih selari on the handicraft of astray. And lastly, Wajik motif are from portion form wajik (wajik petak tabur) and similar title of princess wajik (wajik payung sekaki tajuk puteri) on the handicraft of bag and stationery box. The philosophical local wisdom values of Malay ornaments are the values of good behaviours, taqwa (faith) to Allah, harmony, wisdom, heroic, affection, fertility, self-knowing, fair, responsibility. The result showed that there are some Malay motif ornaments used to develop in the woven gedebong that can be useful to revitalize the Malay philosophical of local wisdom values.
\end{abstract}

Keywords: revitalisasion; motif; malay ornament; woven gedebong

\section{PENDAHULUAN}

Setiap etnis di Indonesia memiliki corak ragam hias atau lebih dikenal dengan istilah ornamen bernilai kearifan lokal budaya. Ragam hias atau ornamen ini sangat kokoh mempengaruhi 
budaya masyarakat setempat dan sebagai jati diri bagi masyarakatnya. Misalnya, bagi masyarakat Melayu, ornamen dijadikan sebagai bagian dari khazanah budaya Melayu. Beberapa corak ornamen Melayu dapat dilihat dalam bentuk ukiran kayu, emas, perak, tenunan kain, sulaman, tekat, suji, dan sebagian yang lain dalam bentuk anyaman baik pandan, bambu, rotan, dan akarakaran. Setiap ornamen tersebut ada yang berasal dari kelompok etnis masyarakat Melayu itu sendiri dan ada pula yang diambil dari budaya masyarakat lain melalui berbagai proses.

Kemahiran dan pengetahuan mengenai corak dan ragam ornamen Melayu ini diwariskan secara turun temurun dari generasi ke generasi kepada masyarakat Melayu. Bagi masyarakat Melayu, corak ornamen ini tidak hanya sebagai hiasan semata, tetapi juga sebagai lambang yang memiliki makna dan falsafah mengenai nilai-nilai luhur budaya masyarakat Melayu. (Juliana \& Fatimah, 2018:131). Namun, karena adanya moderniasasi dan globalisasi perkembangan zaman, beberapa karya budaya Melayu mulai pudar. Salah satu contohnya adalah hasil karya kerajinan anyaman yang bernilai ornamen budaya Melayu. Misalnya, anyaman berornamen filosofi Melayu mulai hilang. Hal ini disebabkan oleh beberapa faktor. Pertama, kurangnya pengetahuan pengrajin dalam menerapkan filosofi ornamen bermotif Melayu pada anyaman. Kedua, pengrajin tidak memamahami makna filosofi yang terkandung pada ornamen bermotif Melayu tersebut. Ketiga, pengetahuan tentang motif ornamen oleh pengrajin kurang sesuai, pengrajin hanya membuat dan tidak menerapkan makna filosofinya. Akibatnya, corak ornamen yang dibuat pada anyaman sama sekali tidak bermakna dan mencerminkan filosofi bduaya Melayu, sehingga menghasilkan produk anyaman yang tidak sesuai dengan filosofi corak kearifan lokal masyarakat Melayu. (Juliana \& Fatimah, 2018:395).

Motif ornamen Melayu pada dasarnya bersumber dari alam, seperti flora, fauna, wajik dan benda-benda angkasa. Benda-benda alam inilah yang direkayasa dalam beberapa bentuk tertentu, baik menurut bentuk asalnya seperti pucuk rebung, kelopak daun, tampuk manggis maupun dalam bentuk sudah dimodifikasi seperti kembang sekawan, berjajar kembang, kelopak mambang sehingga menyebabkan tidak menampakkan wujud asalnya, tetapi hanya menggunakan namanya saja seperti itik pulang petang, semut beriring, dan lebah bergantung. (Malik, 2004:15)

Di antara beberapa ornamen tersebut, motif ornamen yang banyak dipakai masyarakat Melayu adalah yang bersumber pada tumbuh-tumbuhan atau flora. Hal ini dikarenakan masyarakat Melayu pada umumnya beragama Islam sehingga motif hewan atau fauna dikhawatirkan menjurus kepada hal-hal yang berkaitan dengan "keberhalaan". Ornamen bermotif hewan yang dipilih pada umumnya berkaitan dengan mitos atau kepercayaan mayarakat setempat. Misalnya, motif semut dipakai walau tidak dalam bentuk sesungguhnya, disebut semut beriring karena sifat semut yang 
Revitalisasi Filosofi Ornamen Bermotif Melayu pada Desain Corak Anyaman Gedebong Pisang:

Kajian Kearifan Lokal Budaya Melayu

Juliana, Hetty Zaharani

rukun dan tolong-menolong. Begitu pula dengan motif lebah, disebut lebah bergantung, karena sifat lebah yang selalu memakan yang bersih, kemudian madu yang dihasilkan dapat dimanfaatkan orang banyak. Motif naga berkaitan dengan mitos tentang keperkasaan naga sebagai penguasa lautan dan sebagainya. Selain itu, benda-benda angkasa seperti bulan, bintang, matahari, dan awan dijadikan motif karena mengandung nilai falsafah tertentu pula. Ada pula motif yang bersumber dari bentuk-bentuk tertentu yakni wajik, lingkaran, kubus, segi, dan lain-lain. Di samping itu, ada juga motif kaligrafi yang diambil dari kitab Alquran. (Malik, 2004:33)

Dalam tradisi Melayu, motif-motif dasar itu dikembangkan lagi dengan beragam variasi sehingga membentuk suatu perpaduan yang serasi. Bahkan, ada yang menimbulkan nama-nama baru untuk ragam hias yang dimaksud. Motif pucuk rebung, misalnya, berkembang menjadi dua puluh delapan bentuk, motif kaluk pakis menjadi dua puluh bentuk, siku keluang menjadi delapan bentuk. Hal itu selain memperkaya khazanah motif Melayu juga menunjukkan tingginya daya karsa, cipta, dan karya atau kreativitas masyarakat Melayu dalam berseni budaya. Pengembangan motif-motif dasar itu, di satu sisi memperkaya bentuk hiasan. Di sisi lain, pengembangan itu juga memperkaya nilai falsafah yang terkandung di dalamnya. Dengan demikian, tentulah diperlukan usaha untuk revitalisai motif ornamen Melayu untuk dikaji lebih mendalam agar menambah pengetahuan kepada masyarakat khususnya para pengrajin anyaman mengenai asal-usul motif ornamen Melayu dan makna filosofi yang terkadung didalam ornamen tersebut

Untuk itu diperlukan usaha untuk memperkenalkan kembali kepada masyarakat dengan mengoptimalkan potensi Sumber daya manusia dalam mengembangkan dan merevitalisasi anyaman ornamen bermotif Melayu sesuai dengan makna filosofi yang terkandung didalamnya. Berdasarkan fenomena ini, penelitian ini bertujuan untuk merevitalisasi kearifan filosofi ornamen bermotif Melayu pada corak anyaman gedebong sebagai solusi melestarikan dan mempertahankan budaya Melayu. Penelitian ini menghasilkan produk anyaman berornamen Melayu sebagai usaha merevitalisasi kearifan lokal filosofi ornamen bermotif Melayu, sehingga produk anyaman dapat dimanfaatkan dengan baik sebagai usaha pendukung pariwisata dan peluang baru pada industri cinderamata berbasis kearifan lokal.

\section{Definisi Ornamen}

Kata ornamen berasal dari bahasa Latin ornare, yang berarti menghiasi. Dalam buku Ornamen Nusantara menjelaskan bahwa ornamen adalah komponen produk seni yang ditambahkan atau sengaja dibuat untuk tujuan sebagai hiasan. Bentuk-bentuk hiasan yang menjadi ornamen tersebut fungsi utamanya adalah untuk memperindah benda produk atau barang yang dihias. (Sunaryo,2009). Selain itu, menurut Sukarman (1982) ornamen dibuat untuk menghias 
suatu benda atau barang yang bertujuan untuk menghias barang tersebut agar benda/barang yang telah dihias memiliki nilai tambah seperti memiliki keindahan dan menarik dari segi finansial dan spiritual. Dengan kata lain, ornamen adalah penerapan hiasan pada suatu produk.

Pada umumnya, benda yang dihiasi dengan ornamen adalah produk-produk kerajinan tangan atau handicraft misalnya peralatan rumah tangga, tembikar atau keramik, busana dan tekstil, perabot sampai komponen-komponen arsitektur. Ornamen yang digunakan pada suatu produk biasanya memiliki makna kearifan lokal yang melekat pada corak atau motif ornmaen tersebut. Dengan demikian, ornamen tidak dapat dipisahkan dari latar belakang sosial budaya masyarakat setempat.

\section{Makna dan Nilai Ornamen Melayu}

Nilai corak Melayu yang diaplikasikan pada anyaman adalah nilai kearifan filosofi masyarakat Melayu. Nilai filosofi corak berornamen Melayu mengacu kepada sifat asal dari benda atau makhluk yang dijadikan corak dan dipadukan dengan nilai-nilai kepercayaan dan budaya masyarakat Melayu yang terkait dengan nilai luhur agama Islam. (Malik, 2017:97).

Ada empat motif yang mencerminkan filosofi ornamen Melayu. Keempat motif terseut adalah motif flora, motif fauna, motif alam dan motif wajik. Ornamen bermotif fllora biasnaya berasal dari bunga, kuntum, daun, buah, akar. Ornamen bermotif fauna biasanya berasal dari hewan unggas seperti burung, bebek, ayam, binatang reptil seperti pada ular, naga, binatang buas seperti singa, harimau, serangga seperti lebah, kupu-kupu, belalang, binatang air seperti ikan, belut. Ornamen bermotif alam seperti pada bulan, bintang, matahari, awan. dan ornamen bermotif wajik seperti pada ayat alquran.

Motif Ornamen Melayu mengandung nilai-nilai filosofi masyarakat Melayu. Diantaranya adalah nilai Ketaqwaan kepada Allah SWT pada corak bulan sabit, Nilai Kerukunan dalam corak semut beriring, Nilai Kearifan dalam corak burung serindit. Nilai Kepahlawanan dalam motif naga berjuang. Nilai Kasih Sayang dalam bunga bakung, bunga sekuntum, nilai Kesuburan dalam corak pucuk rebung. Nilai Tahu Diri dalam corak bulan penuh. Nilai Tanggung Jawab dalam corak siku keluang, akar berjalin, dan (Maulia, 2015:7).

\section{METODE}

Metode yang digunakan adalah metode kualitatif. Data diperoleh melalui proses pengumpulan data di lapangan. Sumber data berupa gambar ornamen dari bangunan Melayu yang memiliki ukiran bermotif khas Melayu seperti Istana Maimun di Pusat Kota Medan dan 
Revitalisasi Filosofi Ornamen Bermotif Melayu pada Desain Corak Anyaman Gedebong Pisang:

Kajian Kearifan Lokal Budaya Melayu

Juliana, Hetty Zaharani

narasumber penggiat budaya Melayu sebagai narasumber penelitian ini adalah bapak Drs. Fahrizal Nasution serta beberapa literature mengenai ormanen bermotif Melayu.

Data diperoleh melalui dokumentasi, observasi lapangan, dan wawancara. Adapun prosedur pengumpulan data pada penelitian ini adalah (a) Dokumentasi berupa foto gambar ornamen dari bangunan Melayu yang ada di Kota Medan seperti Istana Maimun (b) Observasi lapangan berupa peneliti ke lapangan secara langsung mengamati bangunan ornamen bermotif Melayu (place), Dan (3) Wawancara berupa mewawancarai para tokoh pemuka adat dan peminat ataupun pemerhati seni etnis Melayu di Kota Medan.

\section{HASIL DAN PEMBAHASAN}

\section{Motif dan Nilai Ornamen Bermotif Melayu}

Ada 4 motif yang terdapat pada ornamen Malayu. Keempat motif tersebut adalah:

\section{Ornamen bermotifflora (tumbuh-tumbuhan)}

"Ornamen bermotif Flora" (tumbuh-tumbuhan) adalah ornamen yang berasal dari bentuk bunga, kuntum, daun-daunan, buah dan akar. Corak Bunga pada ornamen Melayu relatif banyak. Bunga yang biasanya digunakan pada ornamen Melayu adalah bunga bakung, bunga melati, bunga kundur, bunga mentimun, bunga hutan, bunga kiambang, bunga cengkih, bunga setaman, bunga serangkai, bunga berseluk, bunga bersanggit, bunga sejurai, bunga kembar, bunga tungga, kembang selari, dan lain-lain.

Corak kuntum yang biasanya digunakan pada ornamen Melayu adalah kuntum tak jadi, kuntum merekah, kuntum serangkai, kuntum bersanding, kuntum kembar, kuntum berjurai, kuntu, jeruju, kuntum setanding, dan sebagainya.

Corak daun yang biasanya digunakan pada ornamen Melayu adalah corak daun bersusun, daun sirih, daun keladi, daun bersanggit bunga, susun sirih penggantin, susun sirih sekawan, daun berseluk, dan sebagainya. Corak buah yang biasanya digunakan pada ornamen Melayu adalah corak buah tampuk manggis, buah hutan, buah delima, buah anggur, buah setangkai, pisang-pisang, pinang-pinang, buah kasenak, buah mengkudu, delima mereka, dan sebagainya. Corak akar yang biasanya digunakan pada ornamen Melayu adalah corak akar kaluk pakis, akar bergelut, akar meililit, akar berpilin, akar berjuntai, akar-akaran, belah rotan, pucuk rebung, dan sebagainya.

Menurut Drs Fahrizal Nasution (hasil wawancara) dalam ornamen "flora" memilki filosofi yang bermakna kerukunan hidup. Masyarakat Melayu dikenal sebagai orang yang sangat menjunjung tinggi nilai kerukunan hidup, baik dalam kehidupan berumah tangga, bermasyarakat, 
berbangsa, maupun bernegara. Nilai kerukunan ini terkandung dalam corak ornament bermotif bunga dua setengger bermakna kerukunan suami istri dan keluarga, dan sebagainya.

Selain itu pada corak ornamen bermotif flora juga terkandung nilai kasih sayang, hormatmenghormati, lemah-lembut, kesucian, ketulusan dan budi pekerti, persahabatan, dan persaudaraan. Nilai-nilai kearifan lokal ini terdapat pada corak ornamen bermotif bunga dan kuntum seperti bunga bakung, bunga sekuntum, bunga cengkih, bunga mentimun, dan sebagainya.

\section{Ornamen bermotiffauna (Hewan)}

"Corak ornamen bermotif fauna" (hewan) adalah ornamen yang berasal dari unggas, hewan melata, hewan buas, serangga dan hewan yang hidup diair. Corak fauna yang digunakan pada ornamen Melayu dari jenis unggas diantaranya adalah itik pulang petang, ayam jantan, ayam bersabung, burung punai, burung bangau, burung serindit, burung balam atau balam dua setengah, burung kurau, garuda menyambar, dan sebagainya. Corak fauna yang digunakan pada ornamen Melayu dari jenis hewan melata diantaranya adalah ular-ularan, ular melingkar, ular tidur, naganagaan, naga bersabung, naga berjuang, naga bertangkup, dan sebagainya. Corak fauna yang digunakan pada ornamen Melayu dari jenis hewan buas diantaranya adalah singa-singaan dan harimau jantan. Corak fauna yang digunakan pada ornamen Melayu dari jenis serangga diantaranya adalah semut beriring, lebah bergantung kupu-kupu, belalang rusa, sepatung berkawan, dan sebagainya. Corak fauna yang digunakan pada ornamen Melayu dari jenis hewan air diantaranya adalah variasi ikan bergelut, ikan sekawan, ketam-ketam atau siangkak hanyut, dan sebagainya.

Menurut Drs Fahrizal Nasution (hasil wawancara) dalam ornamen "fauna" memilki filosofi yang bermakna kerukunan hidup yang dilandasi rasa persatuan dan kesatuan serta kegotongroyongan dan timbang rasa yang tinggi. Nilai ini dapat dilihat pada corak ornamen bermotif semut beriring, itik pulang petang, ikan sekawan.

Selain itu, ornamen "fauna" juga memilki nilai filosofi yang bermakna Kearifan. Sifat arif dan bijaksana menjadi salah satu landasan sifat orang Melayu. Nilai itu terpateri, antara lain, di dalam motif burung serindit yang dimitoskan sebagai lambang kearifan dan kebijaksanaan Melayu. Nilai ini terdapat pada ornamen bermotif naga berjuang, naga bertangkup.

\section{Ornamen bermotif Alam (Benda Angkasa)}

"Corak ornamen bermotif alam" (benda angkasa) adalah ornamen yang berasal dari -benda angkasa seperti bulan penuh, bulan sabit, bulan temaram, bintang-bintang, bintang bertabur, 
Revitalisasi Filosofi Ornamen Bermotif Melayu pada Desain Corak Anyaman Gedebong Pisang:

Kajian Kearifan Lokal Budaya Melayu

Juliana, Hetty Zaharani

bintang bersusun, bintang lima, bintang tujuh, bintang tiga, bintang meninggi hari, matahari pagi, awan larat, avoan bergelut, dan sebagainya.

Menurut Drs Fahrizal Nasution (hasil wawancara) dalam ornamen "benda angkasa" (alam) memilki filosofi yang bermakna Ketaqwaan kepada Allah SWT. Karena mayoritas orang Melayu adalah penganut Islam, nilai-nilai Islam itu banyak mempengaruhi nilai budaya mereka. Nilai ketaqwaan ini, antara lain, dapat dilihat pada corak bulan sabit, bintang- bintang, dan sebagainya.

\section{Ornamen Bermotif Wajik}

"Corak ornamen bermotif wajik" adalah ornamen yang berasal dari bentuk-bentuk tertentu, antara lain adalah segi penjuru empat, segi penjuru enam, segi lima, segi delapan, segi tiga, segi panjang, bulat penuh, bujur telur, lengkung anak bulan, lentik bersusun, dan juga dalam bentuk kaligrafi. Corak ornamen bermotif kaligrafi umumnya mengacu kepada kaligrafi yang berasal dari ayat-ayat suci Alquran.

Menurut Drs Fahrizal Nasution (hasil wawancara) dalam ornamen "wajik" (benda-benda tertentu) memilki filosofi yang bermakna budaya Melayu sangat mematuhi dan menerapkan ajaran agama Islam dalam kehidupan sehari-hari. Nilai ini dapat dilihat pada corak ornamen bermotif segi empat dikaitkan dengan sahabat Nabi Muhammad SAW yang berjumlah empat orang diantaranya Abu Bakar Siddiq, Umar bin Khatab, Usman Bin Affan dan Ali Bin Abi Thalib, bentuk segi lima dikaitkan dengan rukun Islam yang berjumlah lima, bentuk segi enam dikaitkan dengan rukun iman yang berjumlah enam, bentuk wajik dikaitkan dengan sifat-sifat Allah SWT Yang Maha Pengasih lagi Maha Pemurah, serta bentuk bulat dikaitkan dengan sifat Allah Yang Maha Mengetahui dan Penguasa Alam Semesta.

\section{Revitalisasi dan Pengembangan Filosofi Ornamen Bermotif Melayu pada Anyaman Gedebong Pisang}

Beberapa produk anyaman gedebong pisang yang digunakan untuk melestarikan kearifan lokal budaya Melayu dan revitalisasi filosofi ornamen bermotif Melayu adalah pada produk sandal, tas, toples, asbak, tempat tisu, tempat ATK, tempat tusuk gigi dan kotak pensil.

Gambar 1. Filosofi Ornamen Bermotif Fauna Naga Nagaan

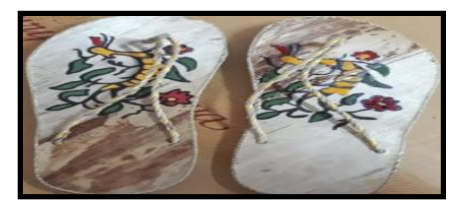


Motif yang digunakan pada produk anyaman gedebong sandal adalah motif fauna naganagaan. Motif corak naga-nagaan ini memiliki makna filosofi yang berkaitan dengan keperkasaan naga sebagai penguasa lautan. Filosofi motif hiasan Naga pada anyaman gedebong adalah bahwa sebagai seorang pemimpin harus memiliki jiwa besar, perkasa, berani, arif, bijaksana.

Dari segi warna pada naga yaitu merah, kuning dan hijau. Makna warna Merah bagi masyarakat Melayu sebagai warna bermakna persaudaraan dan keberanian. Makna warna kuning bagi masyarakat Melayu sebagai warna bermakna kesucian. Warna kuning ini di masa kerajaan Melayu masih berkuasa hanya boleh di gunakan oleh keluarga raja. Dan Warna hijau bagi masyarakat Melayu sebagai warna bermakna kesuburan dan kemakmuran.

\section{Gambar 2. Filosofi Ornamen Bermotif Fauna Semut Beriring}

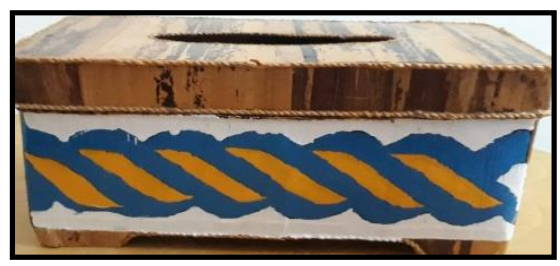

Motif yang digunakan pada produk anyaman gedebong kotak tisu adalah motif fauna semut beriring. Motif semut beriring ini memiliki makna filosofi yang berkaitan dengan sifat semut yang rukun dan tolong-menolong. Filosofi motif hiasan semut beriring pada anyaman gedebong adalah bahwa bagi masyarakat Melayu harus memiliki sikap saling tolong menolong, bekerja sama dan menanamkan sikap rukun dalam persaudaraan dan antar sesama.

Dari segi warna pada semut yaitu biru, kuning dan putih. Makna warna biru bagi masyarakat Melayu sebagai warna bermakna keperkasaan. Pada masa kerajaan Melayu warna biru biasnaya digunakan oleh laksana kerajaan. Makna warna kuning bagi masyarakat Melayu sebagai warna bermakna kesucian. Warna kuning ini di masa kerajaan Melayu masih berkuasa hanya boleh di gunakan oleh keluarga raja. Dan Warna putih bagi masyarakat Melayu sebagai warna kesucian dan dalam tata pakaian adat putih dianggap sebagai tanda kemalangan.

Gambar 3. Filosofi Ornamen Bermotif Fauna Merpati Sekawan

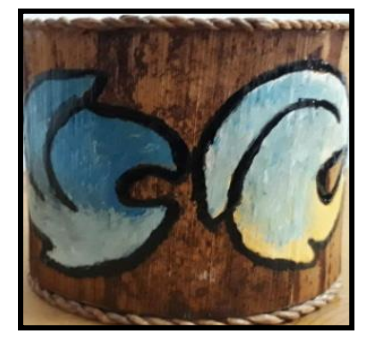


Revitalisasi Filosofi Ornamen Bermotif Melayu pada Desain Corak Anyaman Gedebong Pisang:

Kajian Kearifan Lokal Budaya Melayu

Juliana, Hetty Zaharani

Motif yang digunakan pada produk anyaman gedebong kotak tisu adalah motif fauna merpati sekawan. Motif merpati sekawan ini memiliki makna filosofi berkaitan dengan sikap kesetiakawanan, budi pekerti yang baik dan menawan serta hati yang beriman. Filosofi motif hiasan merpati sekawan pada anyaman gedebong adalah bahwa bagi masyarakat Melayu harus memiliki kesetiakawanan yang tinggi dalam persahabatan, memiliki budi pekerti dan sikap yang baik dalam bertindak dan berkata dan juga memiliki keyakinan yang berlandaskan pada keimanan kepada Allah SWT.

Dari segi warna pada merpati sekawan yaitu biru, kuning dan putih. Makna warna biru bagi masyarakat Melayu sebagai warna bermakna keperkasaan. Pada masa kerajaan Melayu warna biru biasnaya digunakan oleh laksana kerajaan. Makna warna kuning bagi masyarakat Melayu sebagai warna bermakna kesucian. Warna kuning ini di masa kerajaan Melayu masih berkuasa hanya boleh di gunakan oleh keluarga raja. Dan Warna putih bagi masyarakat Melayu sebagai warna kesucian dan dalam tata pakaian adat putih dianggap sebagai tanda kemalangan.

Gambar 4. Filosofi Ornamen Bermotif Itik Pulang Petang

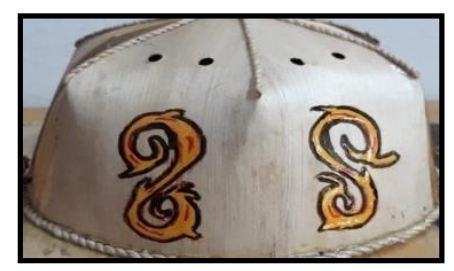

Motif yang digunakan pada produk anyaman gedebong topi adalah motif fauna itik pulang petang. Motif itik pulang petang ini memiliki makna filosofi yang berkaitan dengan kerukunan hidup, baik dalam kehidupan berumah tangga, bermasyarakat, berbangsa, dan bernegara. Orang Melayu sangat menjunjung tinggi kerukunan hidup, hal itu sesuai dalam ungkapan, "senasib sepenanggungan, seaib dan semalu" sehingga "yang berat sama dipikul, yang ringan sama dijinjing".

Dari segi warna pada itik pulang petang yaitu kuning dan hitam. Makna warna kuning bagi masyarakat Melayu sebagai warna bermakna kesucian. Warna kuning ini di masa kerajaan Melayu masih berkuasa hanya boleh di gunakan oleh keluarga raja. Dan Warna hitam bagi masyarakat Melayu sebagai lambang keperkasaan Warna ini selalu dipakai oleh panglima dan hulubalang. 
Gambar 5. Filosofi Ornamen Bermotif Wajik-Wajik

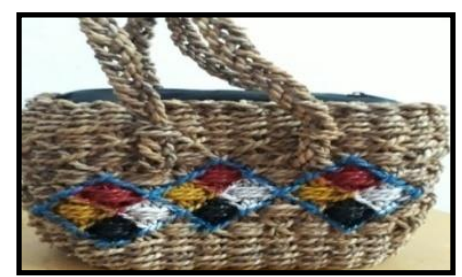

Motif yang digunakan pada produk anyaman gedebong tas adalah motif wajik wajik. Motif ini memiliki makna filosofi yang berkaitan dengan sifat Allah SWT yang Maha Pemurah, Maha Mengetahui dan Menguasai Alam Semesta. Filosofi motif hiasan wajik-wajik pada anyaman gedebong adalah bahwa bagi masyarakat Melayu harus memiliki keyakinan yang berlandaskan pada keimanan kepada Allah SWT Maha pemurah, Mengetahui dan Menguasai Alam Semesta.

Dari segi warna pada wajik-wajik yaitu merah, hitam, kuning dan putih. Makna warna merah bagi masyarakat Melayu sebagai warna bermakna persaudaraan dan keberanian. Masyarakat padalaman menggunakan warna merah sebagai warna keberanian dalam peperangan dan kain merah selalu di kaitkan di pinggang. Warna hitam sebagai warna bermakna keperkasaan. Warna ini selalu dipakai oleh panglima dan hulubalang. Makna warna kuning bagi masyarakat Melayu sebagai warna bermakna kesucian. Warna kuning ini di masa kerajaan Melayu masih berkuasa hanya boleh di gunakan oleh keluarga raja. Dan Warna putih bagi masyarakat Melayu sebagai warna kesucian dan dalam tata pakaian adat putih dianggap sebagai tanda kemalangan.

\section{Gambar 6. Filosofi Ornamen Bermotif Wajik-Wajik}

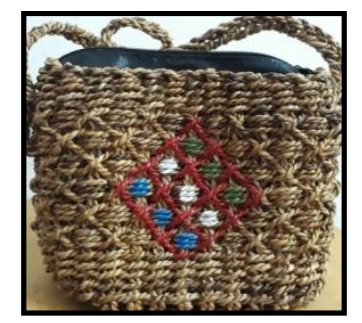

Motif yang digunakan pada produk anyaman gedebong tas adalah motif wajik wajik. Motif wajik wajik ini memiliki makna filosofi yang berkaitan dengan sifat Allah SWT, sifat Allah Yang Maha Pemurah, bentuk bulat dikaitkan dengan sifat Allah Yang Maha Mengetahui dan Penguasa Alam Semesta. Filosofi motif hiasan wajik-wajik pada anyaman gedebong adalah bahwa bagi masyarakat Melayu harus memiliki keyakinan yang berlandaskan pada keimanan kepada Allah SWT Maha pemurah, Maha Mengetahui dan Maha Menguasai Alam Semesta.

Dari segi warna pada wajik-wajik yaitu merah, putih, biru, dan hijau. Makna warna merah bagi masyarakat Melayu sebagai warna bermakna persaudaraan dan keberanian. Warna putih bagi 
Revitalisasi Filosofi Ornamen Bermotif Melayu pada Desain Corak Anyaman Gedebong Pisang:

Kajian Kearifan Lokal Budaya Melayu

Juliana, Hetty Zaharani

masyarakat Melayu sebagai warna kesucian dan dalam tata pakaian adat putih dianggap sebagai tanda kemalangan. Makna warna biru bagi masyarakat Melayu sebagai warna bermakna keperkasaan. Pada masa kerajaan Melayu warna biru biasnaya digunakan oleh laksana kerajaan. Dan makna warna hijau bagi masyarakat Melayu sebagai lambang kesuburan dan kemakmuran.

Gambar 7. Filosofi Ornamen Bermotif Wajik Petak Tabur

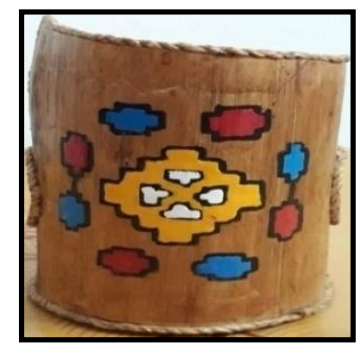

Motif yang digunakan pada produk anyaman gedebong tempat ATK adalah motif wajik petak tabur. Motif wajik petak tabur ini memiliki makna filosofi yang berkaitan dengan sifat Allah SWT sifat Allah Yang Maha Pemurah, bentuk bintang dikaitkan dengan sifat Allah Yang Maha Mengetahui dan Penguasa Alam Semesta. Filosofi motif hiasan wajik petak tabur pada anyaman gedebong adalah bahwa bagi masyarakat Melayu harus memiliki keyakinan yang berlandaskan pada keimanan kepada Allah SWT Maha pemurah, Maha Mengetahui dan Maha Menguasai Alam Semesta.

Dari segi warna pada wajik petak tabur yaitu merah, putih, biru, dan kuning. Makna warna merah bagi masyarakat Melayu sebagai warna bermakna persaudaraan dan keberanian. Warna putih bagi masyarakat Melayu sebagai warna kesucian dan dalam tata pakaian adat putih dianggap sebagai tanda kemalangan. Makna warna biru bagi masyarakat Melayu sebagai warna bermakna keperkasaan. Pada masa kerajaan Melayu warna biru biasnaya digunakan oleh laksana kerajaan. Dan makna warna kuning bagi masyarakat Melayu sebagai lambang kesucian. Warna kuning ini di masa kerajaan Melayu masih berkuasa hanya boleh di gunakan oleh keluarga raja.

Gambar 8. Filosofi Ornamen Bermotif Wajik Payung Sekaki Tajuk Puteri

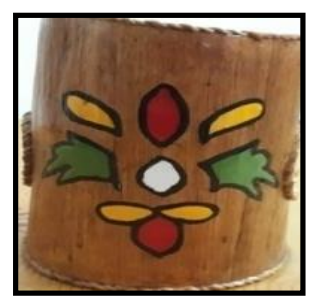

Motif yang digunakan pada produk anyaman gedebong tempat ATK adalah motif wajik payung sekaki tajuk puteri. Motif wajik payung sekaki tajuk puteri ini memiliki makna filosofi 
yang berkaitan dengan sifat Allah SWT Yang Maha Pemurah, bentuk bulat dikaitkan dengan sifat Allah Yang Maha Mengetahui dan Penguasa Alam Semesta. Filosofi motif hiasan wajik payung sekaki tajuk puteri pada anyaman gedebong adalah bahwa bagi masyarakat Melayu harus memiliki keyakinan yang berlandaskan pada keimanan kepada Allah SWT Maha pemurah, Maha Mengetahui dan Maha Menguasai Alam Semesta.

Dari segi warna pada wajik payung sekaki tajuk puteri yaitu merah, putih, kuning, dan hijau. Makna warna merah bagi masyarakat Melayu sebagai warna bermakna persaudaraan dan keberanian. Warna putih bagi masyarakat Melayu sebagai warna kesucian dan dalam tata pakaian adat putih dianggap sebagai tanda kemalangan. Makna warna kuning bagi masyarakat Melayu sebagai lambang kesucian. Warna kuning ini di masa kerajaan Melayu masih berkuasa hanya boleh di gunakan oleh keluarga raja Dan makna warna hijau bagi masyarakat Melayu sebagai lambang kesuburan dan kemakmuran.

\section{Gambar 9. Filosofi Ornamen Bermotif Bunga Berjajar}

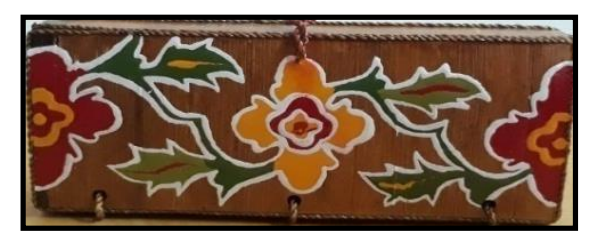

Motif yang digunakan pada produk anyaman gedebong kotak pensil adalah motif bunga berjajar. Motif bunga berjajar ini memiliki makna filosofi yang berkaitan dengan sifat berkelakuan mulia dan hati penyabar. Filosofi motif hiasan bunga berjajar pada anyaman gedebong adalah bahwa bagi masyarakat Melayu harus memiliki sifat mulia yaitu penyabar.

Dari segi warna pada bunga sejajar yaitu merah, putih, kuning, dan hijau. Makna warna merah bagi masyarakat Melayu sebagai warna bermakna persaudaraan dan keberanian. Warna putih bagi masyarakat Melayu sebagai warna kesucian dan dalam tata pakaian adat putih dianggap sebagai tanda kemalangan. Makna warna kuning bagi masyarakat Melayu sebagai lambang kesucian. Warna kuning ini di masa kerajaan Melayu masih berkuasa hanya boleh di gunakan oleh keluarga raja Dan makna warna hijau bagi masyarakat Melayu sebagai lambang kesuburan dan kemakmuran. 
Gambar 10. Filosofi Ornamen Bermotif Bunga Tampuk Manggis

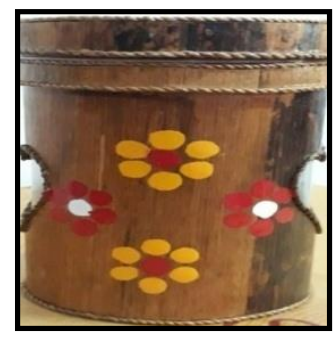

Motif yang digunakan pada produk anyaman gedebong toples adalah motif bunga tampuk manggis. Motif bunga tampuk manggis ini memiliki makna filosofi yang berkaitan dengan budi pekerti dan berlakuan baik. Filosofi motif hiasan tampuk manggis pada anyaman gedebong adalah bahwa bagi masyarakat Melayu harus memiliki budi pekerti dan berlakuan baik.

Dari segi warna pada bunga tampuk manggis yaitu merah, putih, kuning. Makna warna merah bagi masyarakat Melayu sebagai warna bermakna persaudaraan dan keberanian. Warna putih bagi masyarakat Melayu sebagai warna kesucian dan dalam tata pakaian adat putih dianggap sebagai tanda kemalangan. Dan makna warna kuning bagi masyarakat Melayu sebagai lambang kesucian. Warna kuning ini di masa kerajaan Melayu masih berkuasa hanya boleh di gunakan oleh keluarga raja.

\section{Gambar 11. Filosofi Ornamen Bermotif Bunga Kuntum Bujang}

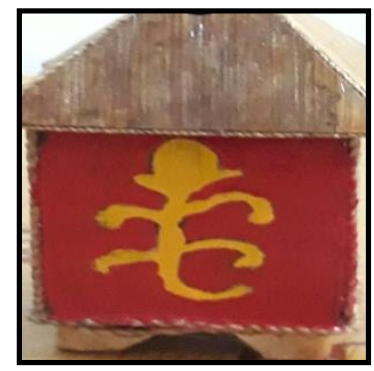

Motif yang digunakan pada produk anyaman gedebong tempat tusuk gigi adalah motif bunga kuntum bujang. Motif bunga kuntum bujang ini memiliki makna filosofi yang berkaitan dengan sikap saling tolong menolong antar sesama serta hidup bahagia rukun dan damai. Filosofi motif hiasan bunga kuntum bujang pada anyaman gedebong adalah bahwa bagi masyarakat Melayu harus memiliki sikap saling tolong menolong antaa sesama dan hidup rukun.

Dari segi warna pada bunga kuntum bujang yaitu merah dan kuning. Makna warna merah bagi masyarakat Melayu sebagai warna bermakna persaudaraan dan keberanian. Dan makna warna kuning bagi masyarakat Melayu sebagai lambang kesucian. Warna kuning ini di masa kerajaan Melayu masih berkuasa hanya boleh di gunakan oleh keluarga raja. 
Gambar 12. Filosofi Ornamen Bermotif Bunga Kuntum Gundur

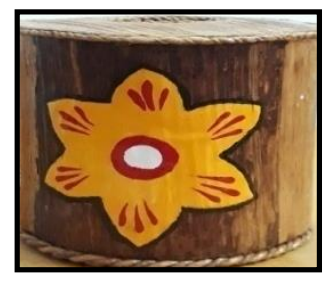

Motif yang digunakan pada produk anyaman gedebong tempat tisu adalah motif bunga kuntum gundur. Motif bunga kuntum gundur ini memiliki makna filosofi yang berkaitan dengan lambang kasih sayang, kesucian, ketulusan dan kehalusan budi pekerti, persahabatan, dan persaudaraan. Filosofi motif hiasan bunga kuntum gundur pada anyaman gedebong adalah bahwa bagi masyarakat Melayu harus memiliki rasa kasih sayang, kesucian, ketulusan dan kehalusan budi pekerti dalam persahabatan dan persaudaraan.

Dari segi warna pada bunga kuntum gundur yaitu merah dan kuning. Makna warna merah bagi masyarakat Melayu sebagai warna bermakna persaudaraan dan keberanian. Dan makna warna kuning bagi masyarakat Melayu sebagai lambang kesucian. Warna kuning ini di masa kerajaan Melayu masih berkuasa hanya boleh di gunakan oleh keluarga raja.

Gambar 13. Filosofi Ornamen Bermotif Kuntum Awan Larat

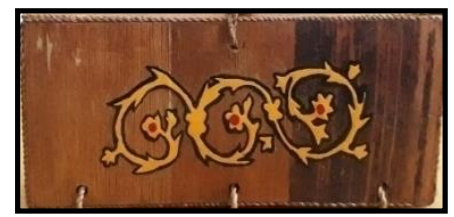

Motif yang digunakan pada produk anyaman gedebong kotak pensil adalah motif kuntumawan larat. Motif bunga kuntum awan larat ini memiliki makna filosofi yang berkaitan dengan lambang kasih sayang dalam persahabatan dan persaudaraan. Filosofi motif hiasan bunga kuntum awan larat pada anyaman gedebong adalah bahwa bagi masyarakat Melayu harus memiliki rasa kasih sayang dalam persahabatan dan persaudaraan.

Dari segi warna pada kuntum awan larat yaitu merah dan kuning. Makna warna merah bagi masyarakat Melayu sebagai warna bermakna persaudaraan dan keberanian. Dan makna warna kuning bagi masyarakat Melayu sebagai lambang kesucian. Warna kuning ini di masa kerajaan Melayu masih berkuasa hanya boleh di gunakan oleh keluarga raja. 
Gambar 14. Filosofi Ornamen Bermotif Bunga Gerak Gempa

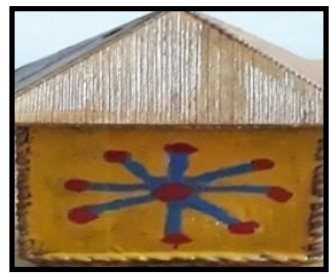

Motif yang digunakan pada produk anyaman gedebong tempat tusuk gigi adalah motif bunga gerak gempa. Motif bunga gerak gempa ini memiliki makna filosofi yang berkaitan dengan keimanan yang kokoh kepada Allah SWT. Filosofi motif hiasan bunga gerak gempa pada anyaman gedebong adalah bahwa bagi masyarakat Melayu harus memiliki keyakinan yang berlandaskan pada keimanan yang kokoh kepada Allah SWT Maha pemurah, Maha Mengetahui dan Maha Menguasai Alam Semesta.

Dari segi warna pada bunga gerak gempa yaitu merah, biru, dan kuning. Makna warna merah bagi masyarakat Melayu sebagai warna bermakna persaudaraan dan keberanian. Makna warna biru bagi masyarakat Melayu sebagai warna bermakna keperkasaan. Pada masa kerajaan Melayu warna biru biasnaya digunakan oleh laksana kerajaan. Dan makna warna kuning bagi masyarakat Melayu sebagai lambang kesucian. Warna kuning ini di masa kerajaan Melayu masih berkuasa hanya boleh di gunakan oleh keluarga raja.

Gambar 15. Filosofi Ornamen Bermotif Buih Selari

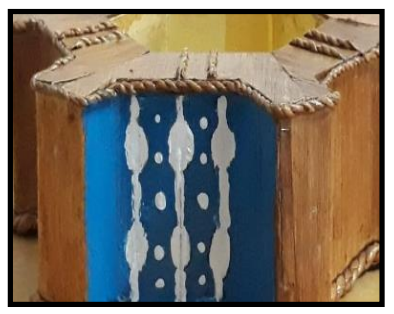

Motif yang digunakan pada produk anyaman gedebong tempat ATK adalah motif buih selari. Motif buih selari ini memiliki makna filosofi yang berkaitan dengan kasih sayang dan keadilan. Filosofi motif hiasan buih selari pada anyaman gedebong adalah bahwa bagi masyarakat Melayu harus memiliki sikap saling mengasihi dan berkelakuan adil.

Dari segi warna pada buih selari yaitu putih dan biru. Makna warna putih bagi masyarakat Melayu sebagai warna kesucian dan dalam tata pakaian adat putih dianggap sebagai tanda kemalangan. Makna warna biru bagi masyarakat Melayu sebagai warna bermakna keperkasaan. Pada masa kerajaan Melayu warna biru biasnaya digunakan oleh laksana kerajaan. 


\section{SIMPULAN}

Ada empat motif yang digunakan dalam merevitalisasi filosofi ornamen bermotif Melayu pada desain anyaman gedebong pisang. Keempat motif ornamen Melayu adalah motif flora, motif fauna, motif alam dan motif wajik. Pertama, ornamen bermotif fllora berasal dari ornamen bermotif bunga berjajar, bunga tampuk manggis, kuntum bujang, kuntum gundur, bunga gerak gempa pada produk kerajinan kotak pensil, kotak tisu, toples kue, tempat tusuk gigi dan kotak tisu. Kedua, ornamen bermotif fauna berasal ornamen bermotif naga-nagaan, semut beriring, merpati sekawan, itik pulang petang pada produk kerajinan kotak tisu, dan topi. Ketiga, ornamen bermotif alam berasal dari ornamen bermotif buih selari pada produk kerajinan asbak. And keempat, ornamen bermotif Wajik pada wajik petak tabur) dan wajik payung sekaki tajuk puteri pada produk kerajinan tas dan tempat ATK.

Nilai-nilai kearifan lokal filosofis ornamen Melayu adalah nilai-nilai budi pekerti, taqwa (keyakinan) kepada Allah, harmoni, kebijaksanaan, heroik, kasih sayang, kesuburan, kemandirian, tanggung jawab.

\section{UCAPAN TERIMAKASIH}

Peneliti mengucapkan terimakasih kepada pihak Kementerian Riset, Teknologi, dan Pendidikan Tinggi Republik Indonesia (KEMENRISTEKDIKTI) yang telah mendanai penelitian ini dalam skim penelitian Dosen Pemula, Universitas Potensi Utama, Nomor: 0547/UPU/PJJ/PPM/VI/2019.

\section{DAFTAR PUSTAKA}

Juliana, J., Fatimah, F., Apriliyanti, A. (2018). Empowering and Fostering Creative Industries Entrepreneurs Based on Local Wisdom of Malay Deli. KARSA: Journal of Social and Islamic Culture, 26(2), 215-250.

Juliana, J., Fatimah, F., Apriliyanti, A. (2018). Pembinaan Penulisan Grafiti Sebagai Wadah Creative Entrepreneur Berbasis Kearifan Lokal Budaya Melayu Deli. Jurnal Ilmiah Lingua Idea, 9(2), 129-143.

Hartanti, G., Nediari, A. (2014). Pendokumentasian Aplikasi Ragam Hias Budaya Bali, Sebagai Upaya Konservasi Budaya Bangsa Khususnya pada Perancangan Interior. Humaniora, 5(1), 521-540.

Kartini, A. (2014). Analisis Penerapan Ornamen Bernuansa Melayu Ditinjau Dari Bentuk Dan Warna Di Kota Medan. (Doctoral dissertation, UNIMED).

Malik, A., Mulyono, S. E. (2017). Pengembangan kewirausahaan berbasis potensi lokal melalui pemberdayaan masyarakat. Journal of Nonformal Education and Community Empowerment, 1(1), 87-101. 
Revitalisasi Filosofi Ornamen Bermotif Melayu pada Desain Corak Anyaman Gedebong Pisang:

Kajian Kearifan Lokal Budaya Melayu

Juliana, Hetty Zaharani

Malik, A., Effendy, T., Junus, H., Thaher, A. (2003). Corak dan Ragi Tenun Melayu Riau. Adicita Karya Nusa, Yogyakarta.

Maulia, R. (2015). Wisata Budaya dalam Tradisi Tenun di Kecamatan Mempura Kabupaten Siak. Jurnal Online Mahasiswa (JOM) Bidang Ilmu Sosial dan Ilmu Politik, 2(2), 1-11.

Sopa, M. (2018). Local Wisdom in the Cultural Symbol of Indonesian Traditional House. KnE Social Sciences, 3(4), 524-531.

Wahyuni, A., Pertiwi, S. (2017). Etnomatematika dalam ragam hias Melayu. Math Didactic: Jurnal Pendidikan Matematika, 3(2), 113-118. 